\title{
ZUSGS
}

science for a changing world

\section{SUMMARY OF GEOPHYSICAL INVESTIGATIONS OF THE DEATH VALLEY REGIONAL WATER-FLOW MODELING PROJECT, NEVADA AND CALIFORNIA}

By Richard J. Blakely, Victoria E. Langenheim, and David A. Ponce

U.S. Geological Survey, 345 Middlefield Road, Menlo Park, CA 94025

Open-File Report 00-189

Prepared in cooperation with the Nevada Operations Office, U.S. Department of Energy (Interagency Agreement DE-AI08-96NV11967)

2000

\section{U.S. DEPARTMENT OF THE INTERIOR}

\section{U.S. GEOLOGICAL SURVEY}

This report is preliminary and has not been reviewed in conformity with U.S. Geological Survey editorial standards or with the North American Stratigraphic Code. Any use of trade, product, or firm names is for descriptive purposes and does not imply endorsement by the U.S. Government. 


\begin{abstract}
This report summarizes geophysical investigations in the Amargosa Desert and surrounding areas conducted between 1997 and 2000 in support of the Death Valley Regional Water-Flow Modeling Project of the U.S. Geological Survey. These investigations used both gravity and aeromagnetic data to develop a regional-scale tectonic and lithologic model for the near-surface. Gravity data were inverted in order to estimate the depth to pre-Cenozoic basement throughout the study area. This basement surface is interpreted to be the contact between pre-Cenozoic carbonate rocks and overlying alluvium, an important component of water-flow models. Gravity data also were used to identify locations where basement rocks are anomalously dense, possibly indicating areas resistant to water flow. A new aeromagnetic survey of the central part of the study area was used to map concealed faults and areas underlain by volcanic rocks.
\end{abstract}

\title{
INTRODUCTION
}

The study area, hereafter referred to as the "halo region", covers approximately $45,500 \mathrm{~km}^{2}\left(17,500 \mathrm{mi}^{2}\right)$ straddling the California-Nevada state line (fig. 1). The halo region includes all of the Nevada Test Site, most of Death Valley National Park, and the towns of Beatty, Amargosa Valley, Furnace Creek, Death Valley Junction, Pahrump, and Shoshone.

The diverse physical properties of lithologies that underlie this region are well suited to gravity and magnetic investigations. The contrast in density between preCenozoic basement and overlying unconsolidated alluvium, for example, produces a distinctive pattern of gravity anomalies that can be used to predict the depth of preCenozoic basement in three dimensions. In most parts of the study area, this surface corresponds to the top of the carbonate aquifer, an important element of the hydrologic framework. Aeromagnetic anomalies, on the other hand, reflect the presence of magnetic rocks in the subsurface. Volcanic flows and deposits, some plutonic rocks, and some Precambrian crystalline rocks are typically more magnetic than pre-Cenozoic carbonate rocks and young alluvial deposits, and thus aeromagnetic anomalies can be used to map 
contacts between these lithologic units. In addition, faults that offset magnetic lithologies often produce small magnetic anomalies, useful for identifying and mapping faults otherwise concealed beneath young deposits.

\section{GEOLOGIC SETTING}

The halo region falls within the southern Basin and Range geologic province and encompasses a large area of diverse geology (fig. 2). The topographic landscape of the area, characterized by vast alluvium-filled basins, rugged mountain ranges, and volcanic edifices, is the result of its long-extensional and erosional history, but the manner in which extension was accommodated is still a matter of discussion. Wright and Troxel (1973) viewed the opening of Death Valley and surrounding basins as occurring along normal faults that terminate at relatively shallow depth (1.5 to $9 \mathrm{~km})$ against gently dipping detachment surfaces. In their view, total horizontal translation of mountain ranges was relatively small. Others (Stewart, 1983; Hamilton, 1988; Wernicke and others, 1988; Holm and Wernicke, 1990) have proposed more dramatic crustal translations along one or more regionally continuous detachment surfaces. Stewart (1983), for example, proposed that the Panamint Range block was initially atop the Black Mountains, both packages abutting the Nopah and Resting Spring Ranges to the east. Beginning in late Cenozoic time, the Panamint Range became detached from the underlying Black Mountains, and both ranges were transported northwestward along one or more regionally continuous detachment surfaces to their present position.

Northwest-striking, right-lateral strike-slip faults also were important in late-stage opening of the largest basins of the Death Valley extended terrane. Central Death Valley, for example, probably formed as a pull-apart basin accomodating strain between the Furnace Creek and Death Valley fault zones (e.g., Burchfiel and Steward, 1966). Similarly, Pahrump Valley and the Amargosa Desert may have opened between rightstepping offsets of the State Line fault zone (Wright, 1988). Recent seismicity indicates that these faults remain active today.

Many of the mountain ranges, including the Funeral Mountains, Black Mountains, Resting Spring Range, Nopah Range, and Spring Mountains, are underlain by Paleozoic 
and older carbonate (limestone and dolomite) and crystalline rocks. Carbonate rocks are believed to be an important aquifer in this part of the Basin and Range (Winograd and Thordarson, 1975; Dettinger, 1989; Laczniak and others, 1996; McKee, 1997), and knowing how these rocks are distributed in the subsurface is important to a full understanding of the hydrologic framework.

Relatively young sedimentary deposits blanket most of the study area, filling vast valleys and basins, such as the Amargosa Desert, Death Valley, and Pahrump Valley (fig. 2). These deposits consist of non-marine sedimentary and volcanic rocks, generally Oligocene and younger in age. They include fluvial conglomerate, sandstone, siltstone, lacustrine claystone and limestone, volcanic ash deposits of various kinds, and local lava flows.

Tertiary volcanism was also an important part of the extensional history of the Amargosa Desert region, especially in the formation of large collapse calderas. Thick Tertiary volcanic sections of the southwest Nevada volcanic field are located in the northern part of the halo region. Volcanic rocks and deposits of Brown Peak and the Greenwater Range are located in the southwestern part of the halo region, within Death Valley National Park (fig. 1).

\section{DATA AVAILABILITY}

Digital versions of the gravity data, the inverse model derived from the gravity data, and the aeromagnetic survey can be downloaded from two anonymous FTP (File Transfer Protocol) sites. Gravity data (plate 1) and the thickness of Cenozoic deposits (plate 2) are available in grid format at

ftp://geopubs.wr.usgs.gov/pub/open-file/00-189/data,

where the following ASCII files can be found:

halogravity.gxf.gz — projected grid of isostatic residual gravity anomalies, halothickness.gxf.gz - projected grid of Cenozoic thickness, and 
halo.info-a detailed description of the gravity and thickness grids.

In addition, the aeromagnetic survey of the Amargosa Desert region is available in two digital formats at

ftp://geopubs.wr.usgs.gov/pub/open-file/00-188/data

(Blakely and others, 2000). The following ASCII files are available:

amargosa.xyz.gz — discrete point measurements along flight lines, amargosa.gxf.gz—projected grid of total-field anomaly values, and amargosa.info-a detailed description of the data.

Point measurements of the aeromagnetic survey (amargosa.xyz.gz) include latitude, longitude, altitude (based on radar altimetry), total-field magnetic anomaly, and various other items. The digital grids (halogravity.gxf.gz, halothick.gxf.gz, and amargosa.gxf.gz) were computed by transforming point data to Universal Transverse Mercator projection, then using a minimum-curvature algorithm to interpolate values to rectangular grid intersections. The gridded data are in Geosoft Grid Exchange Format (GXF), a standard ASCII format for exchanging gridded data among different software systems. GXF is described more fully in the informational files located in the anonymous FTP directories named above. To speed file transfers, the data files have additionally been compressed into the public-domain "gzip" format (as indicated by the suffix .gz). Gzip format is commonly used on PC DOS, PC Windows, Macintosh, and Unix platforms. It too is described more fully in the informational file located in the anonymous FTP directory.

\section{GRAVITY ANALYSIS}

As part of this project, 1,600 new gravity stations were established throughout the halo region using global positioning systems (GPS) or laser total stations to determine 
position and elevation. About 900 of these were collected by the Geophysical Unit, U.S. Geological Survey, Menlo Park, California, the remainder through contract to MWH Geo-Surveys, Inc., Reno, Nevada. Morin and others (1999) provide a description of field techniques. These new data were combined with other publicly available gravity data, and this combined database was used in the subsequent analysis.

The gravitational attraction at any point depends on many factors, including the latitude and elevation of the measurement, earth tides, terrain, deep masses that isostatically support the terrain, and variations in density within the earth's crust and upper mantle. The last of these quantities is of primary interest in geologic investigations and can be obtained by calculating all other quantities and subtracting them from each measurement. The resulting field is termed the isostatic residual gravity anomaly (fig. 3, plate 1) and reflects, to first order, density variations within the middle and upper crust (Simpson and others, 1986).

In the Basin and Range geologic province, isostatic residual gravity anomalies are dominated by the sharp contrast in density between high-density (typically $>2650 \mathrm{~kg} \mathrm{~m}^{-3}$ ) Paleozoic and older rocks exposed in the ranges and low-density (typically $<2450 \mathrm{~kg} \mathrm{~m}^{-3}$ ) unconsolidated to weakly lithified alluvium and volcanic deposits that fill the basins. Thus, the overall pattern of isostatic residual gravity anomalies mimics basin-and-range topography (fig. 3, plate 1). A major exception to this pattern is the southwest Nevada volcanic field (fig. 3, labels SC and TM and surrounding area), where a broad gravity low reflects thick sequences of welded tuff in a group of collapse calderas.

A method developed by Jachens and Moring (1990), modified by Chuchel and Jachens (written commun., 1999), capitalizes on this property in order to separate the gravitational effects of basins and ranges. Their method strives to separate observed gravity into two components: that produced by pre-Cenozoic basement and that produced by overlying basin-filling deposits. The latter component is directly inverted in order to provide the thickness of deposits. The density of basement rocks is allowed to vary horizontally, whereas the density of basin-filling deposits is forced to increase with depth according to specified density-depth relationships (table 1). For sedimentary deposits, we used the density-depth profile of Jachens and Moring (1990), generalized from available well information throughouth the Basin and Range province. For volcanic 
deposits above $1200 \mathrm{~m}$ depth, we used the density-depth profile developed by Hildenbrand and others (1999), based on detailed gravity studies of Pahute Mesa and Oasis Valley, Nevada. Volcanic deposits deeper than $1200 \mathrm{~m}$ were assigned the same density contrast as sedimentary deposits at that same depth (table 1).

The calculation is constrained in places where the depth to pre-Cenozoic basement is known from independent measurements. This information comes from a variety of sources, including digital geology, hydrocarbon-exploration wells (Grow and others, 1994), Department of Energy drill-holes (Ward Hawkins, written commun., 1998), drill logs for water wells from the State of Nevada, an east-west seismic reflection profile north of Devils Hole (Brocher and others, 1993), two seismic reflection profiles in the Crater Flat region (Brocher and others, 1998), and the National Water Information System (G.M. O’Brien, written commun., 1999).

The gravity inversion results in two products, illustrated in figures 4 and 5 and plate 2, respectively: the thickness of basin-filling deposits and the gravitational attraction of pre-Cenozoic basement. The first of these (fig. 4) can be combined with digital elevation data to produce a three-dimensional view of the basement surface, useful in understanding the three-dimensional shape of sub-basins. This three-dimensional surface is an important constraint in developing a model for ground-water flow because basement, often composed of carbonate or crystalline rocks, and unconsolidated deposits that fill the basins have contrasting hydrologic properties.

The basement gravity field (fig. 5) reflects basement lithology, also important to hydrologic models. Several authors (for example, Hamilton, 1988; Stewart, 1983) have proposed that regional detachment surfaces have accommodated crustal extension in the southern Basin and Range. Rocks of the upper plate, above the detachment surface, are characterized as permeable, brittle, and fractured carbonate rocks (McKee, 1997). Rocks of the lower plate, on the other hand, are highly metamorphosed, ductilely deformed, and could act as impediments to the flow of ground water (McKee, 1997). The detachment surface crops out in the Funeral Range and at Bare Mountain, exposing Proterozoic lower-plate siliceous rocks formerly buried to middle crustal depths (Hamilton, 1988). Large basement gravity anomalies (fig. 5) over the Funeral Mountains and Bare Mountain probably reflect lower-plate rocks at shallow depth. 
The basement surface, calculated by subtracting the thickness of Cenozoic deposits (fig. 4) from topography (fig. 1) and shown in figure 7, shows significant relief. Many of the large valleys of the region, notably central Death Valley, the Amargosa Desert, and Pahrump Valley, are underlain by deep, steep-sided sub-basins, in some cases even deeper than their bounding mountain ranges. This rugged terrain reflects in part the tectonic history of the region and will be addressed in a subsequent section.

It is important to understand the limitations of the gravity inversion and the data on which it is based. This calculation is regional in scope and, as such, is intended to highlight the regional distribution of basins and their relative depths and shapes. In order to accomplish this in a reasonable timeframe, grossly simplifying assumptions are required. Although the shapes and relative depths of basins yielded by this method are generally reliable, the calculated thickness of basin-filling deposits depends critically on the density-depth function used in the calculation. We used single density-depth profiles for sedimentary and volcanic deposits, respectively, each generally representative for this region. But densities do vary horizontally from basin to basin and within individual basins, and this will affect our determinations. Moreover, densities of basin-filling deposits below a few kilometers are poorly understood, and the details of the deeper parts of the basins should be viewed accordingly. Finally, basin depths may be in error because of a lack of understanding of the basement gravity field. For example, a lowdensity pluton directly beneath a basin may be incorrectly interpreted by the calculation as extra accumulations of low-density deposits in the basin. This last problem may be of special concern north of latitude $36^{\circ} 40^{\prime} \mathrm{N}$., where volcanic deposits are abundant. Accurate models of specific basins require more detailed gravity modeling, and some examples are described below.

Several recent, site-specific studies in the northern part of the halo region serve as excellent examples of how the same methodology can be used to define detailed threedimensional characteristics of sub-basins. Hildenbrand and others (1999) and Mankinen and others (1999) used geophysical data to characterize structures and lithologies beneath Pahute Mesa and Oasis Valley (fig. 1) and found a topographically complex pre-Tertiary basement surface, also seen on figure 4 and plate 2. Using detailed density information from wells within their study area, they derived a density-depth profile specific to their 
area. The resulting gravity inversion (Hildenbrand and others, 1999) predicts that Pahute Mesa is underlain by more than $5 \mathrm{~km}$ of Tertiary volcanic deposits, whereas deposits beneath Oasis Valley are less than $1 \mathrm{~km}$ thick. They identified a northeast-trending lineation, which they called the Thirsty Canyon lineament, that separates deep, undulating basement to the northwest from a shallow basement surface to the southeast. The structures producing the lineament abruptly truncate four calderas and may reflect a buried fault zone that influenced caldera formation (Hildenbrand and others, 1999).

Phelps and others (1999) used the same methodology to study lithology and structure beneath Yucca Flat (fig. 1). They had a remarkable database at their disposal, consisting of 992 wells, 7,300 gravity stations located within the basin, and 401 gravity stations on surrounding basement outcrop. Their model shows pre-Tertiary basement approximately $2.5 \mathrm{~km}$ below the topographic surface of the valley, somewhat shallower than our determinations for this same region. They also noted undulations of the basement surface, interpreted to be caused by north-striking faults (Phelps and others, 1999).

\section{MAGNETIC ANALYSIS}

In order to identify concealed faults and lithologies, we also conducted a highresolution aeromagnetic survey throughout the central part of the halo region (fig. 1 and 7). The survey was flown during the summer of 1999 with funding from Nye and Clark Counties, Nevada; Inyo County, California; and the National Park Service. The survey covers an area of approximately $7,700 \mathrm{~km}^{2}$, extending from Beatty, Nevada, to south of Shoshone, California. The survey was conducted by Sander Geophysics Limited (SGL) under contract to the U.S. Geological Survey. Data acquisition and processing were accomplished under guidelines established by the U.S. Geological Survey over the last several decades. Flight lines were oriented east-west, spaced $400 \mathrm{~m}$ apart, and flown at an altitude of $150 \mathrm{~m}(500 \mathrm{ft})$ above terrain, or as low as permitted by the Federal Aviation Administration and safety considerations. North-south control lines were spaced $2.3 \mathrm{~km}$ (1.4 mi) apart. Total flight distance was 23,333 km (14,502 mi). Base station magnetometers were deployed at Henderson Field (near Las Vegas) and at Beatty; at 
least one of these magnetometers was in operation at all times of the survey. Base station magnetometers serve two purposes: they record the normal daily changes of the external magnetic field (diurnal variation), which are subsequently subtracted from the aeromagnetic data, and they track the onset and dissipation of magnetic storms. Airborne operations were interrupted if magnetic storm activity exceeded specified limits.

Volcanic rocks are the most ubiquitous magnetic lithology of this region, causing short-wavelength, high-amplitude magnetic anomalies over volcanic terrane in the Yucca Mountain area and over the Greenwater Range. Volcanic sections typically include ashflow tuffs, lava flows, and other sub-horizontal units with uniform directions of magnetization. Steeply dipping faults that offset these layers often produce small magnetic anomalies, lineated along the offset (for example, Bath and Jahren, 1984; Ponce, 1996).

Most Paleozoic carbonate and siliceous stratified rocks of this region are relatively nonmagnetic. An interesting exception is the argillite member of the Devonian- to Mississippian-aged Eleana Formation exposed in the Calico Hills. Baldwin and Jahren (1982) reported an average bulk magnetization of $3.89 \mathrm{~A} / \mathrm{m}$ for the argillite member based on samples recovered from a drill hole in the Calico Hills. For comparison, samples of volcanic rocks from the same area (tuff, tuffaceous beds, and rhyolite intrusions) had magnetizations ranging from 0 to $2.6 \mathrm{~A} / \mathrm{m}$ (Baldwin and Jahren, 1982). See Blakely (1995) for a discussion of magnetic units.

Precambrian rocks in this area sometimes produce distinctive magnetic anomalies. The most prominent magnetic anomaly in Nevada, centered over the Spring Mountains, has been interpreted as being caused by a concealed upwarp of the Precambrian basement (Blank, 1987). Clastic siliceous rocks of the Late Proterozoic and Early Cambrian Wood Canyon Formation exposed at Bare Mountain (Monsen and others, 1992) also have significant magnetizations, and magnetic anomalies over the Black Mountains have been interpreted as being caused by Precambrian basement rocks (Blakely and others, 1999). Why some Precambrian rocks are more magnetic than their younger counterparts is not fully understood. Blakely and others (1999) hypothesized that the magnetic anomaly over the Black Mountains originates from rocks that were once part of deep, relatively 
mafic crust subsequently brought closer to the surface by denudation and uplift. Similar processes may explain manetic anomalies over other Precambrian rocks of this area.

Most of the study area is covered with relatively nonmagnetic alluvial deposits, and alluvium-filled basins are expected to produce only subdued patterns of magnetic anomalies. Several interesting exceptions occur in the Amargosa Desert and Pahrump Valley and will be discussed subsequently.

Various products were derived from the digital aeromagnetic data to assist in the interpretation. Figure 8 shows one example: Residual magnetic anomalies were computed by analytically continuing the aeromagnetic map to a slightly higher surface (Blakely, 1995) and subtracting that result from the original data. This method, essentially a discrete vertical derivative, emphasizes anomalies caused by shallow magnetic sources while subduing anomalies caused by deep sources. It is particularly useful in identifying shallow crustal faults.

Figure 9 shows an interpretation based on the aeromagnetic data. This map-based interpretation emphasizes (1) magnetic lineations that in some cases indicate shallow crustal faults, and (2) magnetic patterns that indicate underlying lithologies. It is based on the original magnetic data (fig. 7), as well as various products derived from these data (for example, fig. 8, this report and fig. 7 of Blakely and others (2000)). This interpretation is regional and qualitative in scope and relies heavily on previously published interpretations of aeromagnetic and ground-magnetic data (Ponce, 1984, 1993, 1996; Ponce and Langenheim, 1994; Ponce and others, 1995; Langenheim, 1995; Langenheim and others, 1993; Louie and others, 1998; Connor and others, 2000). Detailed discussion of the interpretation and a description of individual lineations can be found in Blakely and others (2000).

\section{DISCUSSION}

Figure 10 shows an interpretation of major crustal faults in the halo region, based on our gravity inversion. The black dots on this map show locations of steepest topographic slope on the basement surface. These were calculated automatically and without subjectivity by applying the method of Blakely and Simpson (1986) to the data 
shown in figure 4 . The orange lines identify alignments of maximum slope corresponding to the major sub-basins shown in figure 4 . We interpret these lineations to crudely indicate the location of major range-front and basin-bounding faults. Some of these alignments correspond to mapped basin-bounding faults, perhaps best represented by the east and west margins of central Death Valley (fig. 10, label DV). Others are aligned along, strike-slip fault zones, notably along the Furnace Creek (fig. 10, label F) and Death Valley fault zones (fig. 10, label D).

South of the southwest Nevada volcanic field, these alignments have dominantly northwest-southeast and north-south strikes, reflecting the regional extensional pattern of this part of the Basin and Range. In some cases, basins are aligned on strike with one another, suggesting that they are kinematically linked by a common fault zone. The best example is the alignment of basin-bounding faults along the Nevada-California state line, extending from latitude $37^{\circ} 00^{\prime} \mathrm{N}$. to latitude $35^{\circ} 30^{\prime} \mathrm{N}$., a total distance of about $250 \mathrm{~km}$ (fig. 10, label S-S'). This alignment includes the southeastern margin of the Funeral Mountains and sub-basins beneath Ash Meadows, Pahrump Valley, and Mesquite Valley. Wright (1988) considered the Ash Meadows and Pahrump Valley sub-basins to be transtensional structures that have transferred strain across northwest-striking, rightlateral faults, part of the State Line fault zone.

Rupture along this entire 250-km-long zone of deformation could produce a $\mathrm{M}>7$ earthquake (Wells and Coppersmith, 1994; Louie et al., 1998). Although no moderate to large earthquakes have occurred on this fault in historic time, there is strong evidence from geologic mapping (Hoffard, 1991; McKittrick, 1988; Reheis, 1992; and Donovan, 1991) and detailed geophysical field investigations (Louie and others, 1998; Shields and others, 1998) that it was active during Quaternary time at Pahrump Valley and Ash Meadows.

The Amargosa trough (Blakely and others, 1998, 1999), extending south from the southwest Nevada volcanic field to the State Line fault, is displayed clearly in figure 10 (label A). The eastern boundary of this trough is apparently a major fault, referred to variously as the Amargosa fault (Schweickert and Lahren, 1997) or the gravity fault (Winograd and Thordarson, 1975; Connor and others, 2000), is especially clear in the gravity inversion. The trough may extend southward from the State Line fault to Brown 
Peak (fig. 10, label B) in the Greenwater Range, providing a structural and possible magmatic link between Tertiary volcanism in Death Valley and the Silent CanyonTimber Mountain caldera complex to the north.

Figure 11 shows the spatial relationship between lineations interpreted from highresolution aeromagnetic data (fig. 9) and lineations identified in the gravity inversion (fig. 10). It is not surprising that these two interpretations disagree in detail. First, many of the lineations interpreted from the aeromagnetic data originate from the shallow subsurface $(<1 \mathrm{~km})$, in some cases corresponding to surface faults identified by geologic mapping. Lineations identified from the gravity inversion, on the other hand, originate from the basement surface, often deeper than $1 \mathrm{~km}$ and generally below the source of the aeromagnetic lineations. Second, magnetization and density vary differently across lithologic boundaries. For example, a contact between Paleozoic carbonate rocks and unconsolidated alluvium typically has a large contrast in density but only a negligible contrast in magnetization. Given these disparities, places where gravity and magnetic lineations correspond are of particular interest.

The eastern boundary of the Amargosa trough (fig. 11, label A) is reflected in both the gravity and aeromagnetic interpretations, suggesting that the north-south fault that offsets pre-Tertiary basement is also represented in overlying alluvium. The alignment of springs at Devils Hole (fig. 11, label DH) falls on the eastern margin of the Amargosa trough, possibly because the deposits filling the trough or the fault zone that bounds the trough are impediments to the flow of ground water from the north and east (Blakely and others, 1998). The fault striking southeast from the southern tip of Bare Mountain and crossing the entire Amargosa trough (fig. 11, label C) corresponds at its northwestern end to a small magnetic lineation interpreted to be the Carrara fault (Connor and others, 2000; Blakely and others, 2000).

The State Line fault zone (fig. 11, label S) also is expressed in both the gravity and magnetic interpretations, reflecting both northwest-striking, right-lateral, strike-slip faults and deep pull-apart sub-basins caught within the fault zone. Pahrump Valley (fig. 11, label PV) hosts a particularly interesting segment of the State Line fault, shown in detail in figure 12. Very subtle magnetic anomalies, apparently originating from near the topographic surface, sinuate directly above the deepest reaches of the two sub-basins 
beneath Pahrump Valley (fig. 12). The magnetic anomalies may indicate faults within the Quaternary alluvium, kinematically linked with faults in the pre-Cenozoic basement. Alternatively, the magnetic anomaly may reflect a long fluvial history. The deepest parts of the modern-day sub-basins, for example, may mark their long-term depocenter. Nearsurface magnetic anomalies may originate from magnetic minerals concentrated by fluvial processes along this axis of deposition.

The Furnace Creek fault has both gravity and magnetic expression as it passes from Death Valley through Funeral Wash (fig. 11, label F). The fault zone apparently extends southeastward beyond Brown Peak (fig. 11, label B), where it bends abruptly southward. Dextral slip on the Furnace Creek fault may have produced a transtensional basin at this southeastern end, thus promoting the volcanism responsible for Brown Peak.

\section{CONCLUSIONS}

In this region largely covered by surficial deposits, geophysical methods are critical to understanding the tectonic, hydrologic, and geologic framework. Our regionalscale inversion of gravity anomalies provides a consistent, three-dimensional model of the pre-Cenozoic basement surface for the entire halo region. This concealed surface is significantly more rugged than might be expected from local terrain. In many parts of the halo region, the basement surface corresponds to the contact between pre-Cenozoic carbonate rocks and young alluvium, an important component in models of ground-water flow. The relationship between ground-water flow and basement topography is clearly demonstrated at Devils Hole, Nevada, where springs are aligned directly above an abrupt step in the basement surface. A high-resolution aeromagnetic survey has permitted us to map near-surface faulting, also a product of the long tectonic history of this part of the Basin and Range.

\section{ACKNOWLEDGMENTS}

This report benefited greatly from reviews by Ed Mankinen and Geoff Phelps. Helpful comments also were provided by Gary Dixon, Dennis O’Leary, Chris Potter, and 
Don Sweetkind. Nick Stellavato was instrumental in providing logistical support before and during the aeromagnetic survey. We are grateful to Martin Bates and the survey crew of Sander Geophysics Limited, who acquired and initially processed the aeromagnetic data, and to MWH Geo-Surveys for acquisition of gravity stations.

\section{REFERENCES}

Baldwin, M.J., and Jahren, C.E., 1982, Magnetic properties of drill core and surface samples from the Calico Hills area, Nye County, Nevada: U.S. Geological Survey Open-File Report 82-536, 27 p.

Bath, G.D., and Jahren, C.E., 1984, Interpretations of magnetic anomalies at a potential repository site located in the Yucca Mountain area, Nevada Test Site: U.S. Geological Survey Open-File Report 84-120, 40 p.

Blakely, R.J., 1995, Potential Theory in Gravity and Magnetic Applications: Cambridge University Press, $441 \mathrm{p}$.

Blakely, R.J., Jachens, R.C., Calzia, R.C., and Langenheim, V.E., 1999, Cenozoic basins of the Death Valley extended terrane as reflected in regional-scale gravity anomalies, in Wright, L.A., and Troxel, B.W., eds., Cenozoic Basins of the Death Valley Region: Boulder, Colorado, Geological Society of America Special Paper 333 , p. 1-16.

Blakely, R.J., Langenheim, V.E., Ponce, D.A., and Dixon, G.L., 2000, Aeromagnetic survey of the Amargosa Desert, Nevada and California: A tool for understanding near-surface hydrology: U.S. Geological Survey Open-File Report 00-188, http://geopubs.wr.usgs.gov/open-file/of00-188.

Blakely, R.J., Morin, R.L., McKee, E.H., Schmidt, K.M., Langenheim, V.E., and Dixon, G.L., 1998, Three-dimensional model of Paleozoic basement beneath Amargosa Desert and Pahrump Valley, California and Nevada: Implications for tectonic evolution and water resources: U.S. Geological Survey Open-File Report 98496, 29 p.

Blakely, R.J., and Simpson, R.J., 1986, Approximating edges of source bodies from magnetic or gravity anomalies: Geophysics, v. 51, p. 1494-1498. 
Blank, H.R., 1987, Role of regional aeromagnetic and gravity data in mineral-resource investigations, southeastern Nevada, USGS Research on Mineral Resources1987, Third Annual V.E. McKelvey Forum on Mineral and Energy Resources: U.S. Geological Survey Circular 995, p. 5-6.

Brocher, T.M., Carr, M.D., Fox, K.F., Jr., and Hart, P.E., 1993, Seismic reflection profiling across Tertiary extensional structures in the eastern Amargosa Desert, southern Nevada, Basin and Range province: Geological Society of America Bulletin, v. 105, p. 30-46.

Brocher, T.M., Hunter, W.C., and Langenheim, V.E., 1998, Implications of seismic reflection and potential-field geophysical data on the structural framework of the Yucca Mountain-Crater Flat region, Nevada: Geological Society of America Bulletin, v. 110, p. 947-971.

Burchfiel, B.C., and Stewart, J.H., 1966, "Pull-apart" origins of the central segment of Death Valley, California: Geological Society of America Bulletin, v. 77, p. 439442.

Connor, C.B., Stamatakos, J.A., Ferrill, D.A., Hill, B.E., Ofoegbu, G.I., Conway, F.M., Sagar, B., and Trapp, J., 2000, Geologic factors controlling patterns of smallvolume basaltic volcanism: Application to a volcanic hazards assessment at Yucca Mountain, Nevada: Journal of Geophysical Research, v. 105, p. 417-432. Dettinger, M.D., 1989, Distribution of carbonate-rock aquifers in southern Nevada and the potential for their development, summary of findings, 1985-88: Program for the Study and Testing of Carbonate-Rock Aquifers in Eastern and Southern Nevada, Summary Report No. 1, U.S. Geological Survey, Desert Research Institute, and University of Nevada.

Dohrenwend, J.C., and Moring, B.C., 1993, Reconnaissance photogeologic map of late Tertiary and Quaternary faults in Nevada: Geological Society of America Abstracts with Programs, $89^{\text {th }}$ Cordilleran Section Meeting and $46^{\text {th }}$ Annual Rocky Mountain Section Meeting, v. 25, p. 31.

Donovan, D.E., 1991, Neotectonics of the southern Amargosa Desert, Nye County, Nevada, and Inyo County, California: University of Nevada, Reno, M.S. thesis, 151 p. 5 plates. 
Grow, J.A., Barker, C.E., and Harris, A.G., 1994, Oil and gas exploration near Yucca Mountain, southern Nevada: Proceedings of the Fifth Annual International Conference on High Level Radioactive Waste Management, Las Vegas, Nevada: New York, American Nuclear Society, Inc., and American Society of Civil Engineers, v. 3, p. 1298-1315.

Hamilton, W.B., 1988, Detachment faulting in the Death Valley region, California and Nevada, in Carr, M.D., and Yount, J.C., eds., Geologic and hydrologic investigations of a potential nuclear waste disposal site at Yucca Mountain, southern Nevada: U.S. Geological Survey Bulletin 1790, p. 51-85.

Hildenbrand, T.G., and Kucks, R.P., 1988, Total intensity magnetic anomaly map of Nevada: Nevada Bureau of Mines and Geology Map 93A, scale 1:750,000.

Hildenbrand, T.G., Langenheim, V.E., Mankinen, E.A., and McKee, E.H., 1999, Inversion of gravity data to define the pre-Tertiary surface and regional structures possibly influencing ground-water flow in the Pahute Mesa-Oasis Valley region, Nye County, Nevada: U.S. Geological Survey Open-File Report 99-49 26 p.

Hoffard, J.L., 1991, Quaternary tectonics and basin history of Pahrump and Stewart Valley, Nevada and California: University of Nevada, Reno, M.S. thesis, 138 p., 5 plates.

Holm, D.K., and Wernicke, B., 1990, Black Mountains crustal section, Death Valley extended terrain, California: Geology, v. 18, p. 520-523.

Jachens, R.C., and Moring, B.C., 1990, Maps of thickness of Cenozoic deposits and the isostatic residual gravity over basement for Nevada: U.S. Geological Survey Open-File Report 90-404, scale 1:1,000,000.

Jennings, C.W., 1977, Geologic map of California: California Division of Mines and Geology Geologic Map No. 2, scale 1:750,000.

Laczniak, R.J., Cole, J.C., Sawyer, D.A., and Trudeau, D.A., 1996, Summary of hydrogeologic controls on ground-water flow at the Nevada Test Site, Nye County, Nevada: U.S. Geological Survey Water Resources Investigations Report 96-4109, 59 p. 
Langenheim, V.E., 1995, Magnetic and gravity studies of buried volcanic centers in the Amargosa Desert and Crater Flat, southwest Nevada: U.S. Geological Survey Open-File Report 95-564, 36 p.

Langenheim, V.E., Kirchoff-Stein, K.S., and Oliver, H.W., 1993, Magnetic investigations of buried volcanic centers near Yucca Mountain, Nevada: American Nuclear Society Proceedings of the Fourth Annual International Conference on Hih-Level Waste Management, v. 2, p. 1840-1846.

Lienkaemper, J.J., 1985, Quaternary fault map of California in digital format: U.S. Geological Survey Open-File Report 85-211, 14 p., magnetic tape.

Louie, J., Shields, G., Hasting, M., Plank, G., and Bowman, S., 1998, Shallow geophysical constraints on displacement and segmentation of the Pahrump Valley fault zone, California-Nevada border, in Lund, W.R., editor, Proceedings of the Basin and Range Province Seismic Hazards Summit, May 13-15, 1997: Utah Geological Survey, Cedar City, Utah.

Mankinen, E.A., Hildenbrand, T.G., Dixon, G.L., McKee, E.H., Fridrich, C.J., and Laczniak, R.J., 1999, Gravity and magnetic study of the Pahute Mesa and Oasis Valley region, Nye County, Nevada: U.S. Geological Survey Open-File Report 99-303, $57 \mathrm{p}$.

McKee, E.H., 1997, Evaluation of geologic structure guiding ground water flow south and west of Frenchman Flat, Nevada Test Site: U.S. Geological Survey OpenFile Report 97-734, 26 p.

McKittrick, M.A., 1988, Surficial geologic map of the Resting Springs and Nopah Ranges, Inyo County, California, and Nye County, Nevada: U.S. Geological Survey Miscellaneous Field Studies Map MF-1941, scale 1:62,500.

Monsen, S.A., Carr, M.D., Reheis, M., and Orkild, P.J., 1992, Geologic map of Bare Mountain, Nye County, Nevada: U.S. Geological Survey Miscellaneous Investigations Map I-2201, scale 1:24,000, 6 p.

Morin, R.L., Chuchel, B.A., and Blakely, R.J., 1999, Principal facts for about 500 gravity stations in the vicinity of Amargosa Desert and Pahrump Valley, California and Nevada: U.S. Geological Survey Open-File Report 99-31, 18 p. 
Phelps, G.A., Langenheim, V.E., and Jachens, R.C., 1999, Thickness of Cenozoic deposits of Yucca Flat inferred from gravity data, Nevada Test Site, Nevada: U.S. Geological Survey Open-File Report 99-310, 33 p.

Ponce, D.A., 1984, Gravity and magnetic evidence for a granitic intrusion near Wahmonie site, Nevada Test Site, Nevada: Journal of Geophysical Research, v. 89, p. 9401-9413.

Ponce, D.A., 1993, Geophysical investigations of concealed faults near Yucca Mountain, southwest Nevada: American Nuclear Society Proceedings of the Fourth Annual International Conference on High Level Waste Management, v. 1, p. 168-174.

Ponce, D.A., 1996, Interpretive geophysical fault map across the central block of Yucca Mountain, Nevada: U.S. Geological Survey Open-File Report 96-285, 15 p., 4 plates.

Ponce, D.A., and Langenheim, V.E., 1994, Preliminary gravity and magnetic models across Midway Valley and Yucca Wash, Nevada: U.S. Geological Survey OpenFile Report 94-572, 25 p.

Ponce, D.A., Sikora, R.F., Roberts, C.W., Morin, R.L., and Halvorson, P.F., 1995, Magnetic investigations along selected high-resolution seismic traverses in the central block of Yucca Mountain, Nevada: U.S. Geological Survey Open-File Report 95-667, 23 p.

Reheis, M.C., 1992, Aerial photographic interpretation of lineaments and faults in late Cenozoic deposits in the Cactus Flat and Pahute Mesa 1:100,000 quadrangles and the western parts of the Timpahute Range, Pahranagat Range, Indian Springs, and Las Vegas 1:100,000 quadrangles, Nevada: U.S. Geological Survey Open-File Report 92-193, 14 p. text, 3 plates, scale 1:100,000.

Roberts, C.W., and Jachens, R.C., 1999, Preliminary aeromagnetic anomaly map of California: U.S. Geological Survey Open-File Report 99-440, 14 p., http://geopubs.wr.usgs.gov/open-file/of99-440.

Schweickert, R.A., and Lahren, M.M., 1997, Strike-slip fault system in Amargosa Valley and Yucca Mountain, Nevada: Tectonophysics, v. 272, p. 25-41.

Shields, G. Allander, K. Brigham, R., Crosbie, R., Trimble, L., Sleeman, M., Tucker, R., Zhan, H., and Louie, J.N., 1998, Shallow geophysical survey across the Pahrump 
Valley fault zone, California-Nevada border: Bulletin of the Seismological Society of America, v. 88, p. 270-275.

Simpson, R.W., Jachens, R.C., Blakely, R.J., and Saltus, R.W., 1986, A new isostatic residual gravity map of the conterminous United States with a discussion on the significance of isostatic residual anomalies: Journal of Geophysical Research, v. 91, p. $8348-8372$.

Stewart, J.H., 1983, Extensional tectonics in the Death Valley area, California: Transport of the Panamint Range structural block 80 km northwestward: Geology, v. 11, p. $153-157$.

Stewart, J.H., and Carlson, J.E., 1978, Geologic map of Nevada: U.S. Geological Survey, scale 1:500,000.

Wells, D.L., and Coppersmith, K.J., 1994, New empirical relationships among magnitude, rupture length, rupture width, rupture area, and surface displacement: Bulletin of the Seismological Society of America, v. 84, p. 974-1002.

Wernicke, B.P., Axen, G.J., and Snow, J.K., 1988, Basin and Range extensional tectonics near the latitude of Las Vegas, Nevada: Geological Society of America Bulletin, v. 100, p. 1738-1757.

Winograd, I.J., and Thordarson, W., 1975, Hydrogeologic and hydrochemical framework, south-central Great Basin, Nevada-California, with special reference to the Nevada Test Site: U.S. Geological Survey Professional Paper 712-C, 126 p.

Wright, L.A., 1988, Overview of the role of strike-slip and normal faulting in the Neogene history of the region northeast of Death Valley, California-Nevada, in Ellis, M.A., ed., Selected papers from the workshop, Late Cenozoic evolution of the southern Great Basin, Reno, Nevada, November 10-13, 1987, p. 1-11.

Wright, L.A., and Troxel, B.W., 1973, Shallow-fault interpretation of Basin and Range structure, southwestern Great Basin, in Dejong, K.A., and Scholten, R., eds., Gravity and tectonics: New York, John Wiley, p. 397-407. 
Table 1.-Density-depth profile for Cenozoic deposits used in three-dimensional gravity inversion. The sedimentary density-depth profile is from Jachens and Moring (1990). The volcanic density-depth profile above $1200 \mathrm{~m}$ depth is from Hildenbrand and others (1999). Below $1200 \mathrm{~m}$, volcanic deposits were considered to have densities equal to sedimentary deposits at that same depth.

\begin{tabular}{|c|c|c|}
\cline { 2 - 3 } \multicolumn{1}{c|}{} & \multicolumn{2}{c|}{ Density contrast, $\mathrm{kg} / \mathrm{m}^{3}$} \\
\hline Depth Range, m & sedimentary deposits & volcanic deposits \\
\hline $0-200$ & 2020 & 1900 \\
$200-600$ & 2120 & 2100 \\
$600-1200$ & 2320 & 2300 \\
$>1200$ & 2420 & 2420 \\
\hline
\end{tabular}

